\title{
ドイッの樹木葬墓地にみる新たな森林利用
}

\section{A Study on Woodland Burials as a New Forest Use in Germany}

\author{
上田 裕文*
}

Hirofumi UEDA

\begin{abstract}
This study clarified the factors of spreading wood burials in Germany comparing with Japanese challenges of them. The actual state of wood burials in Germany was figured out through literature researches, fieldworks and interview researches. German wood burial is placed as a new forest use in addition to the multiple public functions of forest. In contrast, Japanese wood burial is a new form of graveyard. In addition to that, German wood burials are managed by private enterprises which contract with forest owners and controlled by foresters in a sustainable nature based forest management. This is the reason why the wood burials in Germany look similar and are continued with surrounding forest areas. Japanese wood burials have already diversified and some forest type wood burials are usually managed by Buddhist monks, which face similar challenges in sustainable forest management.
\end{abstract}

Keywords: woodland burial, forest use, Germany キーワード：樹木葬墓地, 森林利用, ドイツ

\section{1. はじめに}

少子高齢化が進む中，日本でも墓地問題が社会的な関心となっ ている。槙村は, 明治以降の近代墓地の成立から現代に至る過程 で，本来墓が持つ性格の「尊巌性」，「永続性」，「固定性」が，「個 人化」,「無縁化」,「流動化」し, さらに,「共同化」,「無形化」, 「有期限化」の要素が, 現在進行中の墓地の形態変化に見られる と指摘する。人々の意識は，先祖供養から自分自身の死後設計一 と向かい，これまで家族が継承する永続性を前提としていた家族 墓は，家族構造の変化や承継者の不在により無縁化し個人化する 傾向にある 1)。都市への人口移動などにより，血縁だけでなく地 縁も失った墓は, 「墓じまいりブームに代表されるように流動化し, 一方では放棄された無縁墓の増加も危惧されている。こうした墓 地の循環利用を促進する, 墓地の有期限化や，さらには墓地の継 承すらも必要としない自然葬も増加する一方で，合葬墓や新たな コミュニティでの共同墓も増加している。このように，近年の社 会構造の変化に伴う墓地形態のめまぐるしい変化は，確実に将来 の異質なランドスケープとして国土に現れてくると考えられる。

こうした墓地問題を，社会的な視点から一歩引き，生命の循環 や物質循環といった生態学的視点から捉え直すと，ランドスケー プとしての墓地のあり方という異なる議論が可能になるだろう。 本研究では, 自然葬の中の樹木葬墓地に焦点を当て, 人の営みと 自然の営みの相互作用の結果として現れる, ランドスケープとし ての墓地の今後のあり方を考察する。

樹木葬墓地とは, 墓碑の代わりに樹木を用いる埋葬方法である。 日本の自然葬や樹木葬に関する先行研究としては, 森 2)や金 3)な どの, 社会制度的な研究がみられる。また, 武田 ${ }^{4}$ はイギリスの 自然葬地のケーススタディを通して，新たな緑地景観としての樹 木葬墓地の研究を行っている。しかしながら，新たな森林利用や 里山保全の可能性として樹木葬墓地を位置づけ, その先行事例と してのドイツに注目した研究は未だに見られない。

日本は近代化の中で，ドイツより森林科学を導入した歴史があ
り, 林業をはじめとする森林利用や管理方法に多くの類似点を見 ることができる5)。そんな中，両国では近年，共通して樹木葬墓 地が誕生し関心を集めている。しかし，ドイツにおいてどのよう に樹木葬墓地が誕生し普及しているのかの現状を，ランドスケー プの視点から明らかにした研究は見られない。自然環境の管理, 特に新たな森林利用といら観点から樹木葬墓地を展開寸るための 有用な知見が得られると考えられる。

\section{2. 研究の目的と方法}

本研究では, 近年関心が高まる樹木葬墓地に関して, ドイツの 現状を把握し日本と比較考察することで, 社会問題と連動して変 化する墓地形態と, それに伴う自然管理の可能性を明らかにする。 具体的には，(1）樹木葬墓地が誕生した社会的な背景，(2) 空間 的な特徵と管理運営方法に焦点を当て, ドイツにおける樹木葬 墓地普及の要因を分析するとともに，日本における課題を 具体的に整理することを目的とする。

樹木葬墓地の社会的な背景に関して, 樹木葬墓地の開設に関わ った当事者達へのインタビュー調査とともに文献調査を行った。 ドイツで最初の樹木葬墓地を開設した有限会社「FriedWald（安 らぎの森)」と, 日本で最初の樹木葬墓地である知勝院とで, 樹木 葬墓地誕生の背景等についてインタビュー調査を行った。ドイツ の埋葬文化の変化については, ドイツ埋葬文化博物館にて事務局 長に対してインタビュー調査を行った。
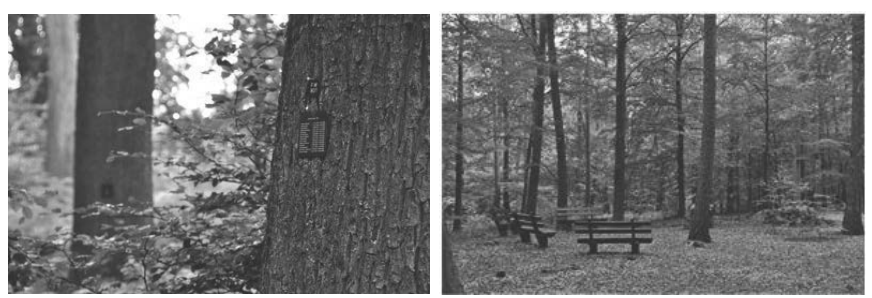

図－1 ドイツの樹木葬墓地 (Reinhardswald, Schwanberg)

* 札幌市立大学デザイン学部 

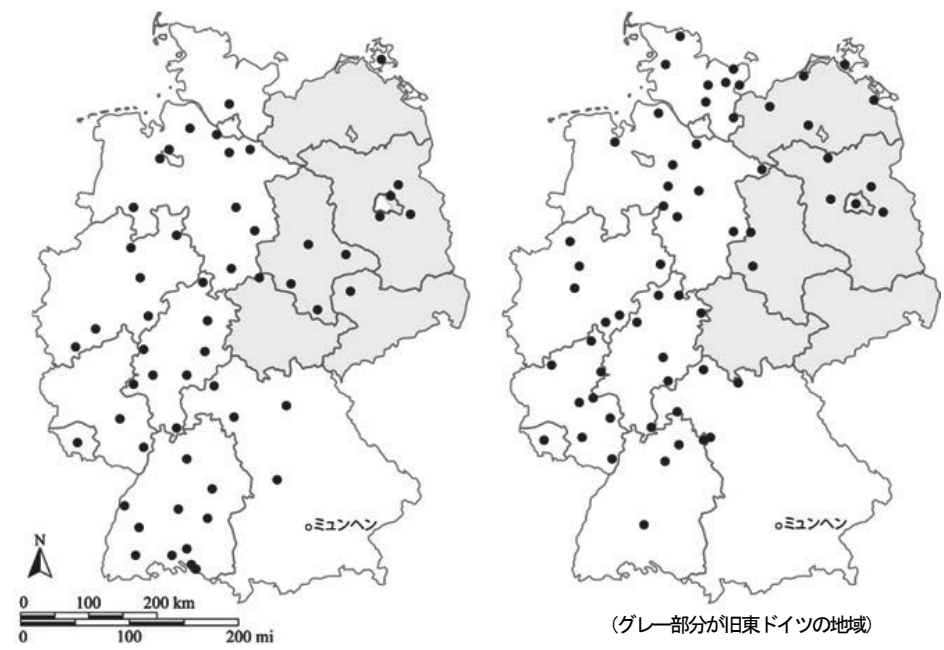

図一2 FriedWald(左), RuheForst (右)の樹木葬墓地の分布

樹木葬墓地の空間的特徵に関して，ドイツの主要な樹木葬墓地 運営会社である，有限会社「FriedWald（安らぎの森）」と

「RuheForst (静寂の林)」をドイツの樹木葬墓地の代表とし, 選 定の基準や管理運営の状況についてインタビュ一調査を行った。

また，それぞれの運営会社が最初に開設した樹木葬墓地

Reinhardswald と Huemmel をはじめ, 教会有林

（Schwanberg），民有林（Kaufungen）といった異なる森 林所有形態を持つドイツの樹木葬墓地にて，現地調査および森 林官や管理者へのインタビュ一調査を行った。日本において は, 最初期の樹木葬墓地である知勝院をはじめ, 民営墓地 である，町田いずみ浄苑や北斗霊園，公営墓地として整備 された横浜市のメモリアルグリーン，東京都の小平霊園な どで同様の現地調查およびヒアリングを行った。

\section{3. 樹木葬墓地が誕生した社会的背景}

\section{（1）樹木葬墓地の原型となった森林墓地}

ドイツにおける樹木葬墓地は，「宗教に左右されない，社会的 義務からの自由」という理念を掲げ2001年にヘッセン州カッセル 郡Reinhardswald（ラインハルトの森）でその第一号がオープン した。公共的な性格が強かった埋葬に個人の選択が入り込む余地 を与え, 墓の維持管理の負担から遺族を解放する点から，ドイツ 社会に大きなインパクトを与えた。契約者は, 家族やパートナー, 友人グループ, 単身者などが気に入った樹種や樹齢の木を選び, 土に還る天然素材の骨盇に焼骨を入れて埋蔵される。墓碑代わり になる木には名前が刻まれたプレートが付けられる6)。

ドイツにおけるこうした森林と墓地の関係は，20世紀はじめに まで逆る。18世紀から19世紀の初めに, 人口の急増, 世俗化, 衛 生的，美的な理由で，多くの都市では中世教会広場が閉鎖され， 市域内での埋葬が禁止になった。そして, 行政が墓地の管理を引 き継いだ。1850年ごろからは, 墓地の設計は次第にガーデンデザ インやランドスケープデザインの課題になり, 数多くの「公園墓 地」が発生した。このころ, 場所の節約の為に火葬が再び許可さ れるようになった。そして, 産業革命後の1900年ごろ, 工業社会 への批判や自然回帰運動などが，墓地の構造や墓碑のデザインに まで影響を与え「ミュンヘン森林墓地」のような例外的なコンセ プトが誕生した7)。1907年にオープンした森林墓地は, Hans Grässelによって森林の中に計画された墓地である。雰井気を統一 するため, 墓石のサイズや形状と加工に関する規則ができること で，墓地形態が厳しく制限された。その後，多くのドイツの都市 は，ミュンヘンのこの事例を見本にしたため，森の墓地と墓碑の 形状を統一寸る規則がドイツ全土へと普及し一般化した8)。

ドイツ埋葬博物館の Eppler は, ドイツにおける樹木葬墓地の
原型として, 森林墓地とならび，芸術家のネクロポーレを挙げる 9)。1992 年, カッセル市では, Harry Kramer の「芸術家のネク ロポーレ」という前例のない墓地プロジェクトが行われた。アー トプロジェクトの企画の中で，芸術家たちは生前に森の中に自分 の墓石になる作品を作った。これらの作品は，すでに整備された 墓域におかれたわけではなく, 自然のままの森の中に制作された。 さらに, 墓地を経営するのに必要な法的な条件をわざと避けるこ とでプロジェクトを成立させた。ドイツでは，墓地を経営する権 利があるのは, 市町村または, 宗教団体 (キリスト教, ユダヤ教) で，その条件は芸術家には絶対満たすことができない。カッセル の「ネクロポーレ」は芸術的には高く評価されているにも関わら ず，墓地関係者（墓地管理人，石大工，墓地の庭師など）に無視 された。もしも，専門家がこのアートプロジェクトをしっかりと 理解していれば, ドイツの墓地のその後の発展や変化に関して準 備ができたはずだと Eppler は述べる。

\section{（2）樹木葬墓地の誕生}

ドイツの銀行投資家 Axel Baudach は法律学者の Petra Bach と一緒に, 樹木葬墓地の有限会社 FriedWald を立ち上げ, 墓地の森を経営しようとした。老齢の樹木が立っている森を探し, その木の根元に骨劽を埋葬する方法で樹木葬墓地としての指定を 受けようとした。このアイディアは，スイスで樹木葬墓地を始め たUeli Sauter から得たものであった。しかし，スイスとは異な り, ドイツには墓地一の埋葬を義務づける法律があるため, 既存 の教会墓地か，地方自治体の公営墓地以外の新たな埋葬地の選択 肢はなかった。さらに，日本と同様に墓地経営は地方自治体や宗 教法人, 公益法人に限られ, 民間会社の墓地経営は法律上不可能 であった。それにも関わらず，彼らは法律の隙間を見つけ，ドイ ツにそれまでなかった新たな墓地を開設することに成功した ${ }^{10)}$

ドイツではどの市町村でも墓地を開設したり, 経営したりする ことが可能で，その墓地の広さや大きさは，実際に住んでいる人 口に関係なく決めることができる。Reinhardswald は, 森林のみ からなる独立した自治体であり，その全ては州に管理される州有 林である。そのため，森林局はその村の代表（首長）も兼ねてお り, 墓地を作る権利も有している。また, 住民が存在しないため, 住民対応や議会といった手続きを経ることなく，森林局はフーテ バルド（かつての放牧用林）を墓地に指定し，その管理を有限会 社 FriedWald に委託したのである。有限会社は, 運営主体として, 契約者を募集するサービス業務全般を担う 11)。このような協力関 係の背景には, 1990 年の終わりごろからの, 林業の経済的な危機 が挙げられる。州有林としては, 林業経営状況の改善のため, 有 限会社から支払われる借地料が必要であった ${ }^{12)}$

このように, ドイツで最初の樹木葬墓地は, Reinhardswald が持っていた特殊な地域的, 政治的事情お よび経済的事情により実現したものであった。しかし，そ の先例に基づいてこの動きは一気に全国に拡大していった。

\section{（3）樹木葬墓地のドイッ国内での普及}

樹木葬墓地誕生から 10 年以上が経ち, ドイツでは 500 力所 以上の樹木葬墓地が指定され, 樹木葬墓地の埋骨容量は 200 万体 分と予測されている。ドイツの消費者団体Aeternitas の資料によ ると，その内訳は，94\%が行政の管理責任下，5\%は教会が経営 し, 残りの $1 \%$ は不明である。有限会社FriedWald にも競合会社 ができ，現在は FriedWald と RuheForst の 2 社が全国展開を行 っている企業である 13) (図-2)。

このように，樹木葬墓地は，教会や行政の墓地の競合相手とな り, その結果, 従来型の墓地の状況をも劇的に変化させた。既存 の宗教的な葬送の様式を破壊するものとして, 当初キリス 卜教団体は樹木葬墓地に強く反対し, 抗議キャンペーン等 も行われた 14)。しかし, 教会有林の樹木葬墓地が 2007 年 
に Schwanberg で誕生し，プロテスタント教会を中心に樹 木葬墓地が広まっている ${ }^{15)}$ 。宗教者が墓地契約や葬儀，そ の後の参拝の対応を行うことから 16), 遺族へのグリーフケ アを含む新たな樹木葬墓地の展開を見ることができる。こ のことは，樹木葬墓地誕生から 5 年以上が経ち，契約者が 多様化する中で, 樹木葬が脱宗教的な信条とは無関係な, 墓地の一形態としての地位を獲得したことを意味している と言える。それでも，カトリックが強く保守的な習慣が残 るミュンヘンでは今でも火葬率が低く 17)，樹木葬墓地はあ まり受け入れられていない現状がある（図-2）。

\section{（4）日本の樹木葬墓地との比較考察}

日本での樹木葬墓地は, 1999 年に一関市の知勝院にて始まった。 当初は, 住職が地域の環境保全運動と平行して開設した樹木葬墓 地であったが，その後「樹木葬」という形式がさまざまに解釈さ れ，後述するように，多様な墓地形態を生みながら全国に広がっ ていった ${ }^{18)}$ 。その多くは既存の墓地の一角を樹木葬墓地として整 備したものが殆どで，新たな森林利用と見なせる森林型の樹木葬 墓地はほとんど見られない19)。

日本とドイツでほぼ同時期に始まった樹木葬墓地だが，いずれ も，新たな法整備が行われたわけではなく，現状の法的枠組みの 範囲内で新たな樹木葬墓地という形態が現れ，社会に広がってい った点は興味深い。しかし，新たな事業として民間運営会社が普 及させたドイツの樹木葬は, 森林を所有する公共団体や宗教団体 等に新たな森林経営の選択肢を提供した。一方で，日本における 樹木葬は, 墓地形態の多様化のひとつであり, 森林経営としての 側面は持っていないと言える。

ドイツでは，森林空間と墓地空間の両者が社会的に公共 空間と位置づけられており，その両者が重なるところに樹 木葬墓地空間が誕生したと言える ${ }^{20)}$ 。歴史的には，ロマン 主義の流れで発生した森林墓地が，近年の樹木葬墓地の原 型となっており, 施設整備という点からは両者は異なるが, 自然の中での埋葬を実現するという目的は共通している。 ドイツでは森林と墓地が結びつく下地が 100 年かけて整っ ていたと言える。

\section{4. 空間的特徵と管理運営方法}

\section{（1）樹木葬墓地の経営主体と運営主体}

ドイツの樹木葬墓地のトップシェアを争う FriedWald と RuheForst であるが，実際には FriedWald に不満を持った林業 家たちが，同じアイディアを用いて新規の民間会社として設立し たのが RuheForst である。しかも, 2003 年に 2 番目の FriedWald としてオープンしたノルトライン-ヴェストファーレン州の Huemmel が, 脱退後翌年に RuheForst 第一号として再オープン した。このような背景から，両者の樹木葬墓地の形態や運営方法 は極めて類似している。重要な相違点は，FriedWaldが，林地を 借り受けて樹木葬墓地を設置するのに対し, RuheForst は各森林 所有者によるフランチャイズとして展開した点である 20)。そのた め, 前者の方が運営会社による墓地の質の統一が図られており, 後者のほうが森林経営という視点から所有者ごとの多様な展開が 見られる。森林所有者が，運営業務の量と収入のバランスを考慮 して選択することが可能で, 自治体などの公有林では運営業務を 任せられる FriedWald を選択し，民有林では収入の多い RuheForst を選択する傾向がある 21)。際興味深いのは, ドイツ も日本と同様, 墓地経営主体は地方公共団体を原則とし, その他宗教法人または公益法人に限られる。しかしながら， 民有林であっても，これらの経営主体（地方自治体）と墓 地の永続性を保証する契約 (Traegerschaft) を結ぶことで,

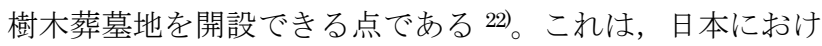

る民営の事業型墓地が, 寺院などの宗教法人の「名義貸し」 によって開発されるのに似ている。

\section{（2）森林の選定基準と将来像}

運営会社ごとの統一ブランドという意味で，ドイツの樹 木葬墓地は全国どこでも，ほぼ共通のサービスを提供して いる。このことは，墓地の空閒的特徴についても言え，墓 地利用に適した姿の森林区域が樹木葬墓地に選定されてい る。その基準は, 30ha 以上の静かな広葉樹を主体とした混 交林で, 都市部からのアクセスが容易な交通インフラの整 備された場所である。その他にも, 水源保安林に指定され ておらず, 斜面が緩やかで岩が少ないといった基準もあり, これらは概ね, 州ごとに定められた既存の墓地法

(Friedhofs- und Bestattungsgesetz)に従った基準である。 混交林の森が好まれるという条件から，マツ等の大規模な 人工針葉樹林が多い旧東ドイツの地方には，樹木葬墓地が 少ないという傾向がある（図-2）23)。

樹木葬墓地の，森林としての空間的特徵を支える時間的 スケールは，その契約期間に表れている。FriedWald では， 樹木葬墓地としての土地の使用期間が 99 年間である。こ れは，樹木葬墓地開設後，購入の時期が遅いほど契約期間 が短くなることを意味している。しかし，ドイツでは，一 般的な公営墓地の契約年数が 20 年前後であることから, 最長で 99 年契約が結べる樹木葬墓地は, 森林と同様の永 続的な時間スケールと見なされている24)。FriedWald は, 借地による樹木葬墓地の運営であるため, 土地の使用権が 墓地の借地契約の期間となっているが，RuheForst では， 各森林所有者が墓地購入者と直接契約を結ぶ形を取るため, 契約期間が 99 年間保証されているという違いがある。開 設から間もない現在では大きな違いはないが，今後，その 契約期間の差が開いてくることになる。

樹木葬墓地によって, その混交林の構成樹種や林齢はさ まざまである。高木を中心に構成される森林は, 将来的には原 生林に近づいていくと考えられている。しかし，いずれの樹木葬 墓地管理者も 99 年契約終了後の土地利用については明言を避け ている。樹木葬墓地がいずれ自然保護区になると考える管理者も いるが 25)，一方で成長後の樹木の材木利用の可能性について語る 管理者もいるなど 26$)$, ドイツの樹木葬墓地もはっきりとした将来 像と持続性が確立されているわけではない。

\section{（3）管理運営方法}

ドイツの樹木葬墓地は, 森林官によって他の施行林とと もに管理され，全体の森林経営の中で運営方針等が決まっ ている。その管理理念は, 80 年代の酸性雨に代表される, 環境意識の高まりを反映した，近自然型林業による長伐期 施業を前提としている。墓地利用は森林の多面的利用の一 形態として位置づけられており, 具体的には, 木材生産や狩 猟といった利用は制限されるが，生物の生息地や人間のレクリエ ーション空間を提供する場として，適切な交通整備が行われ，歩 道を除く林床や倒木等に関しては近自然的な粗放管理が行 われている 27)。そして，樹木葬墓地を担当する森林官の新 たな業務として，樹木葬墓地の見学会の開催や，契約の際 の樹木選定の案内, 葬儀への立会いと場合によっては埋葬 までが加わった。開設当初は, 新たな自然回帰のイメージ 定着のため, 完全に宗教色を排除していた樹木葬墓地だが, 近年は林内に十字架や礼拝場所を設ける樹木葬墓地も見ら れる。

樹木葬墓地と一般的な森林との違いは, 利用者の安全管理が求 められる点である。一般的な森林の場合は, 歩行者の自己責任に よる通行が認められるが，樹木葬墓地になると，倒木や落枝に関 
する安全管理が求められる。当初想定されていなかった支障木の 剪定作業が必要となり，管理者の間では問題視されている。一般 的な墓地とは異なり，バリアフリーが徹底されていない自然空間 であるため，今後契約者遺族の高齢化が進んだ時，樹木葬墓地の 参拝が可能であるかも疑問視されている 28)。

\section{（4）日本の樹木葬墓地との比較考察}

日本の樹木葬墓地では，最初に作られた知勝院では里山 保全の理念と実践が見られるものの，全国的に見ると，「樹 木葬」の定義そのものも曖昧であり, 多様な形態の樹木葬 墓地が拡大している。そのほとんどは，林内に焼骨を埋蔵 後，苗木を植樹するもの，シンボルツリーとなる大木の周 囲に遺骨を埋蔵するもの, 従来型の墓所区画に墳墓に変わ るガーデニングのような整備を行うもののいずれかである 29）当然のことながら，自然景観としての樹木の成長を前 提とした管理計画を持っているところはなく，継続的に管 理が必要な半人工的な空間となっている。特に，地方自治 体によって経営される公営墓地では, 地域住民への不足す る墓地需要を満たすことが最重要命題となることから，樹 木葬墓地は効率的な墓地供給を可能にする一手段と見なさ れている。その結果, 樹木葬墓地は自然葬としてではなく, 墓地の共同化による合葬墓の一形態として位置づけられる 傾向にある ${ }^{30)}$ 。

このように，運営会社が主導して全国に整備されたドイツの樹 木葬墓地と, 全国各地の各経営主体が独自に整備した日本の樹木 葬墓地では，その空間的特徽に大きな差異がある。森林に整備さ れた樹木葬墓地に絞つたとしても，林内に立つ高木の根元に埋葬 するドイツの樹木葬と，地中への埋葬後に花木の苗木を植樹する 日本の樹木葬では，自ずと樹木葬墓地の景観に違いが見られる。 森林がそのまま墓地として使用されるドイツと，森林を墓地とし て整備し直し，その中に墓碑としての樹木が並ぶという違いであ る。これに伴う, 樹木葬墓地の管理に見られる最大の相違点は, ドイツが森林管理そのものであるのに対し，日本は墓地管理であ ると言う点であり，このことは土地利用計画にも現れている。ド イツの樹木葬墓地の土地利用区分は「森林地域」のままで，墓 地開発による他用途転用とは見なされない。10 年ごとに作 成される森林施業計画において, その森林の機能区分は「墓 地機能」と分類される ${ }^{31)}$ 。これに対し日本の森林法では, 墓地は「住宅地に準ずる土地として使用される土地」とし て「森林」から除外される。また, ドイツでは土地所有者, 運営会社，森林管理者（国家公務員である森林官）の三者が分か れるのに対し，日本では全てが管理計画も含めて土地所有者であ る僧侶や自治体などが行っているのが一般的である。そのため, 持続的な樹木葬墓地の森林としての整備に，日本は大きな課題を 抱えていると言える。

\section{5. おわりに}

少子高齢化などの社会構造の変化に共通点があり，ほぼ同時期 に樹木葬墓地がスタートしたドイツと日本であるが，その誕生の 経緯やその後の展開, 管理運営の状況には多くの相違点があった。

まず，ドイツの樹木葬墓地は，森林そのものを墓地として利用 するものであり，逆を言うと，森林の多面的な公益機能に加え， 新たな利用として埋葬が位置づけられている。これに対し，日本 の樹木葬は, 墓石に変わる, 新たな墓地や墓碑の形態を提供した のみで，自然環境の管理としての視点は乏しい。

次に, ドイツでは運営会社が主導して全国に樹木葬墓地を開設 したため，老龃の混交林といった共通した空間的特徵が見られる のに対し，日本では各墓地経営者の創意工夫によって多様な樹木 葬墓地が現れている。その管理運営においても，ドイツの樹木葬
墓地は，土地所有者，運営会社，森林管理者（森林官）の三者の 役割分担が明確で，長期にわたっての持続的な森林管理が行われ るのに対し, 日本の樹木葬墓地は, 従来型の墓地管理の延長線上 にあり，長期的な自然環境の保全には至っていない。

さらに，ドイツでは，森林の持つ公益性と永続性から，民有林 を活用した樹木葬墓地を, 地方自治体による管理責任という形で 整備することを可能にしている。このことは，森林資源の新たな 活用方法として，ドイツ全土の森林に新たな人と金の流れを生む ことにつながり，ランドスケープに与える影響も少なくない。

その他に特筆すべきは，ドイツにおける樹木葬墓地の誕生は， 日本とも類似する現行の法的枠組みの範囲内で実現し, 森林文化 として定着した点である。現在日本が抱える墓地問題と自然環境 保全の問題を考えると, 今後, ドイツと同様の樹木葬墓地が展開 する可能性も皆無ではない。もちろん，気候風土などの地理的条 件，宗教や死生観などの文化的条件に違いはあるとしても，日本 における樹木葬墓地が独自の森林文化と結びつくことで，持続的 なランドスケープとして発展し定着することが期待される。

\section{補注・用文献}

1）槙村久子(2013)：お墓の社会学一社会が変わるとお墓も変わる:晃洋書房, pp228

2）森謙二(2000) : 墓と葬送の現在一祖先祭祀から葬送の自由八: 東京堂出版, pp325

3) 金亮希・永田信 (2008) : 新たな墓地形態としての樹木葬墓地の現状と今後の課題: 林業経済, 60(10), $2-7$

4）武田史朗（2005）：英国における自然葬地軍動とその制度的枠組みの発生およひ発展プロセス 68(5), $809-812$

5) 北村昌美 (1995) : 森林と日本人一森の心迫る : 小学館, pp413

6）有限会社FriedWald 広報担当, Corina Brod 氏へのヒアリングより 2010.9 .23

7) Arbeitsgemeinschaft Friedhof u. Denkmal e.V. (2003) : Raum für Tote: Die Geschichte der Friedhöfe von der Gräberstrasse der Römerzeit bis zur anonymen Bestattung : Haymarket Media, pp296

8) Sylvie Assig (2007) : Waldesruh statt Gottesacker. Der Friedwald als neues Bestattungskonzept : ibidem-Verlag, pp168

9）埋葬尃物館事務局長, Gerold Eppler 氏へのヒアリングより 2011.9.16

10) Sylvia Frevert (2010) : FriedWald : Die Bestattungsalternative, Guetersloher Verlagshaus, pp176

11） Reinhardswald 元森林官 Herman-Josef Rapp 氏へのヒアリングより 2013.3 .22

12） Reinhardswald 森林局長 Norbert Teuwsen 氏へのヒアリングより 2013.3 .22 Aeternitas e.V. ホームページ

$<$ http://www.naturbestattungen-online.de/inhalt/definition/baumbestattung> : 2015.9.20 参 照

14） RuheForst Huemel 森林官 Peter Wohlleben 氏へのヒアリングより 2013.3.24

15） Brod氏へのヒアリングより

16） Schwanberg 修道院の Hildegard Schwegler 氏へのヒアリングより 2011.9.14

17) 鯖田 豊之 (1990) : 火葬の文化 : 新潮社, pp206 究補助金分担研究報告書, $141-152$

31） Tauwsen 氏へのヒアリングより 